\title{
Rapid detection of Mycoplasma synoviae by loop-mediated isothermal amplification
}

\author{
Olimpia Kursa • Grzegorz Woźniakowski • \\ Grzegorz Tomczyk $\cdot$ Anna Sawicka $\cdot$ Zenon Minta
}

Received: 10 September 2014 / Revised: 27 October 2014 / Accepted: 12 November 2014 / Published online: 21 November 2014

(C) The Author(s) 2014. This article is published with open access at Springerlink.com

\begin{abstract}
Mycoplasma synoviae (MS) remains a serious concern in production of poultry and affects world production of chickens and turkeys. Loop-mediated isothermal amplification (LAMP) of DNA has been recently used for the identification of different economically important avian pathogens. The aim of this study was to develop LAMP for simple and inexpensive detection of MS strains in poultry using specifically designed primers targeting hemagglutin A (vlh) gene. The assay was conducted in a water bath for $1 \mathrm{~h}$ at $63{ }^{\circ} \mathrm{C}$. The results were visualized after addition of SYBR Green ${ }^{\circledR}$ fluorescent dye. LAMP was specific exclusively for MS without cross-reactivity with other Mycoplasma species. The sensitivity of LAMP was determined as $10^{-1} \mathrm{CFU} / \mathrm{ml}$ and was 1,000 times higher than MSspecific polymerase chain reaction. LAMP assay was conducted on 18 MS field strains to ensure its reliability and usefulness. This is the first report on LAMP development and application for the rapid detection of MS isolated from chickens. This simple method may be applied by diagnostic laboratories without access to expensive equipment.
\end{abstract}

Keywords Mycoplasma synoviae $\cdot$ Loop-mediated isothermal amplification $\cdot$ Rapid detection

Communicated by Michael Berney.

O. Kursa $\cdot$ G. Tomczyk $\cdot$ A. Sawicka $\cdot$ Z. Minta

Department of Poultry Diseases, National Veterinary Research

Institute, Partyzantów 57 Avenue, 24-100 Puławy, Poland

G. Woźniakowski ( $\square)$

Department of Poultry Viral Diseases, National Veterinary

Research Institute, Partyzantów 57 Avenue, 24-100 Puławy,

Poland

e-mail: grzegorz.wozniakowski@ piwet.pulawy.pl

\author{
Abbreviations \\ AIV Avian influenza virus \\ ATCC American Type Culture Collection \\ B3 Forward backward primer \\ BIP Backward inner primer (B1c + B2) \\ Bst Thermostabile enzyme isolated from Bacillus \\ smithii bacteria \\ CAV Chicken anaemia virus \\ CFU Colony-forming unit \\ F3 Forward outer primer \\ FIP Forward inner primer $(\mathrm{F} 1 \mathrm{C}+\mathrm{F} 2)$ \\ HI Hemagglutination-inhibition test \\ IBV Infectious bronchitis virus \\ LoopF Forward loop primer \\ LoopB Backward loop primer \\ NDV Newcastle disease virus \\ MS Mycoplasma synoviae \\ MG Mycoplasma gallisepticum \\ PCR Polymerase chain reaction \\ SPA Serum plate agglutination \\ vlh Hemagglutin A gene of MS
}

\section{Introduction}

Mycoplasma synoviae (MS) infections are common and main cause of chronic subclinical upper respiratory disease, infectious synovitis, and airsacculitis in chickens and turkeys (Kleven 2003; Ferguson-Noel and Noormohammadi 2013). Similar to Mycoplasma gallisepticum (MG) MS infections have a great economical impact on the commercial poultry industry causing growth retardation, weight loss, and decreased egg production (King et al. 1973; Kleven 2003; Feberwee et al. 2008; Catania et al. 2010; Ferguson-Noel and Noormohammadi 2013). Its exact effect in layer chicken 
industry is still a current topic of investigations because of a recently found new clinical form called eggshell apex abnormalities described in several countries (Feberwee et al. 2009; Catania et al. 2010; Landman 2014). An effective treatment of its clinical form was successfully treated using tylosin, administered in the drinking water for 5 days (Catania et al. 2010). However, the most preferred method of MS control in poultry flocks is its eradication (Olson et al. 1956; Stipkovits and Kempf 1996; Fiorentin et al. 2003).

Lateral transmission of MS occurs by direct contact and spreads between the birds kept in the same poultry house (Kleven et al. 1975; Ewing et al. 1998; Ferguson-Noel and Noormohammadi 2013). Infection is transmitted via the respiratory tract and usually $100 \%$ of birds become infected. In spite of the clinical form of the disease visible as joint lesions is not always observed, the infected birds remain carriers of MS (Ewing et al. 1998; Kleven 2003). MS infections most frequently occur as a chronic subclinical upper respiratory infection (Landman and Feberwee 2004). Meanwhile, not all chicken flocks showing high antibody levels against MS suffer from infectious synovitis (Jordan 1975; Kleven et al. 1975; Ferguson-Noel and Noormohammadi 2013). Some factors including age of birds, flock size and farming conditions may affect severity of MS in poultry flocks. Taking into account these aspects, rapid and efficient diagnostics of MS is an important issue not only for prevention of clinical disease progress but also infection transmission (Landman 2014).

So far, MS diagnosis has been carried out by bacteriological isolation, serological assays, or polymerase chain reaction and its modification (PCR, multiplex PCR or real-time PCR) (Lauerman et al. 1993; Hong et al. 2004; Hess et al. 2007; Feberwee et al. 2008; Hammond et al. 2009; Raviv and Kleven 2009; Dijkman et al. 2013, Fraga et al. 2013; Reck et al. 2013). The sensitivity of direct MS culturing from affected joints is low and often yields negative results, especially in the sub-chronic stage of the disease (Salisch et al. 1998). Furthermore, direct MS culturing is generally expensive and time consuming because it takes up to 28 days. In serological methods, sera collected from infected birds are commonly analysed for the presence of antibodies by serum plate agglutination (SPA) test, seldom by hemagglutinationinhibition (HI) test or enzyme-linked immunosorbent assay (ELISA) (Ewing et al. 1998; Feberwee et al. 2008).

Although there are many PCR-based methods for detection of MS, they are still laborious, time consuming and require advanced laboratory equipment (Hong et al. 2004; Hammond et al. 2009; Raviv and Kleven 2009; Wetzel et al. 2010; Fraga et al. 2013; Reck et al. 2013).

An advance in detection of many different human and animal pathogens was loop-mediated isothermal amplification (LAMP) developed by Notomi et al. (2000). LAMP depends on auto-cycling strand displacement DNA synthesis performed by Bst or Bsm DNA polymerase using two or three sets of primers complementary to six or eight different regions in the gene of interest ( $\mathrm{Fu}$ et al. 2011). LAMP uses a set of inner primers (forward FIP and backward BIP primer), outer primer (including F3 and B3) and forward and backward loop primers (FL and BL) which enable faster formation of loop and hairpin-like structures thus faster detection of specific DNA. Amplification is performed under isothermal conditions of $60-65{ }^{\circ} \mathrm{C}$, while the final products form cauliflower-like structures with multiple overhangs (Notomi et al. 2000; Woźniakowski et al. 2011).

LAMP method has been widely applied for the diagnosis of bacteria like Shigella spp., Salmonella spp, E. coli (Fu et al. 2011) as well as viral and fungal disease in human and animals (Saito et al. 2005; Huang et al. 2010; Yang et al. 2010; Woźniakowski et al. 2012; Mair et al. 2013; Kakuya et al. 2014). Some of them are economically important poultry pathogens thus LAMP facilitated an improvement in their efficient detection.

The objective of this study was to develop LAMP for the detection of MS without the need of thermal cycler application using water bath or heating block. This is the first report on the development of LAMP for the specific MS identification.

\section{Materials and methods}

\section{Strains}

Seven reference Mycoplasma spp. strains purchased from ATCC collection comprising of $M$. synoviae (ATCC 25204), M. gallisepticum (ATCC 19610), M. meleagridis (ATCC 25284), $M$. iowae (ATCC 33552), M. anatis (ATCC 25524), M. anseris (ATCC 49234) and M. cloacale (ATCC 35276) were used. Additionally, 18 field isolates of MS collected during the years 2010-2014 were included. These strains were isolated and identified at the Department of Poultry Diseases at the National Veterinary Research Institute (NVRI, Pulawy, Poland).

\section{DNA extraction}

Extraction of genomic DNA from MS reference strains and field isolates was conducted using the QIAamp Mini Kit (Qiagen, Hilden, Germany) following the manufacturer's instructions. The DNA samples were stored at $-70{ }^{\circ} \mathrm{C}$ until further analysis.

\section{LAMP}

Based on the $v l h A$ sequence of SB5654 MS strain (Accession number: KC506824), six complementary primers were 
designed using Primer Explorer V4 software (NetLaboratory, Tokyo, Japan) and manual assignment. The primer sequences are listed in Table 1. LAMP reactions were conducted in $15 \mu \mathrm{l}$ of reaction mixtures which contained: $7.5 \mu \mathrm{l}$ of Isothermal Mastermix (OptiGene, Horsham, West Sussex, United Kingdom), $10 \mathrm{pM}$ of each inner primer FIP and BIP, $2.5 \mathrm{pM}$ of each outer primer F3 and B3, $5 \mathrm{pM}$ of "loop" primers: LoopF and LoopB primer, $1.5 \mu \mathrm{l}$ of deionised water and $2 \mu \mathrm{l}$ of DNA template.

The reaction mixtures were incubated at the temperature range from 56 to $70{ }^{\circ} \mathrm{C}$ for a different time (from $30 \mathrm{~min}$ to $105 \mathrm{~min}$ ) and subsequently heated up to $80^{\circ} \mathrm{C}$ for $2 \mathrm{~min}$ to inactivate the enzyme. After this step, $1 \mu \mathrm{l}$ of $1: 10$ dilution of $10,000 \times$ concentrated SYBR Green ${ }^{\circledR}$ (Invitrogen,
Paisley, UK) was added to each sample. Results of LAMP were observed by naked-eye, under UV light or after gel electrophoresis in $2 \%$ agarose gels stained with ethidium bromide $(0.5 \mu \mathrm{g} / \mathrm{ml})$. The length of LAMP products was compared to 100-bp DNA Ladder Plus GeneRuler ${ }^{\mathrm{TM}}$ (Thermo-scientific, Waltham, Massachusetts, USA). The colour of reaction mixtures in negative controls was orange, while the positives showed green colour or greenish fluorescence. The sensitivity of LAMP was tested using nine 10-fold dilutions $\left(10^{6}-10^{-2} \mathrm{CFU} / \mathrm{ml}\right)$ of DNA extracted from MS reference strain (ATCC 25204) with the entire titre $1 \times 10^{6} \mathrm{CFU} / \mathrm{ml}$. The analytical specificity was tested using DNA extracted from six different Mycoplasma spp. reference strains.

Table 1 Sequences of LAMP primers used in the study

\begin{tabular}{llr}
\hline Primer & Sequence $\left(5^{\prime}-3^{\prime}\right)$ & Length $(\mathrm{nt})$ \\
\hline F3 & GGTGATCAAACTCCAGCA & 18 \\
B3 & TAACCGATCCGCTTAATGC & 19 \\
FIP $($ F1c + F2) & CTCCTGGGTTTCCTGGGTTTCCCTGCTCCAACACCTGG & 38 \\
BIP $($ B1c + B2 $)$ & TTGACCCTGTAGAGGCTGCTAGCATCTGCTGTTGTAGTTGT & 41 \\
LoopF & TGGGTTTCCTGGATTTGGG & 19 \\
LoopB & GCTATTGATGCTGCAACAGAAT & 22 \\
\hline
\end{tabular}

F3, forward outer primer; B3, forward backward primer; FIP, forward inner primer (F1C + F2); BIP, backward inner primer (B1c + B2); LoopF, forward loop primer; LoopB, backward loop primer

Fig. 1 Analytical sensitivity of LAMP and PCR for MS detection. a PCR detection of $v$ lhA fragment. The product length is $375 \mathrm{bp}$ and was indicated with an arrow. b LAMP. Visible colour change in MS-positive samples, greenish fluorescence under UV light and specific ladder-like patter after gel electrophoresis. Descriptions $M$ molecular length marker GeneRuler ${ }^{\mathrm{TM}} 100$ bp DNA Ladder Plus (Thermo-scientific, Waltham, Massachusetts, USA), 10-fold dilutions of reference M. synoviae strain (ATCC 25204): $110^{6} \mathrm{CFU} / \mathrm{ml}, 210^{5}$ $\mathrm{CFU} / \mathrm{ml}, 310^{4} \mathrm{CFU} / \mathrm{ml}, 410^{3}$ $\mathrm{CFU} / \mathrm{ml}, 510^{2} \mathrm{CFU} / \mathrm{ml}, 610^{1}$ $\mathrm{CFU} / \mathrm{ml}, 710^{0} \mathrm{CFU} / \mathrm{ml}, 810^{-1}$ $\mathrm{CFU} / \mathrm{ml}, 910^{-2} \mathrm{CFU} / \mathrm{ml}$, and $N C$ negative control-DNA extracted from non-inoculated growth medium
(A)

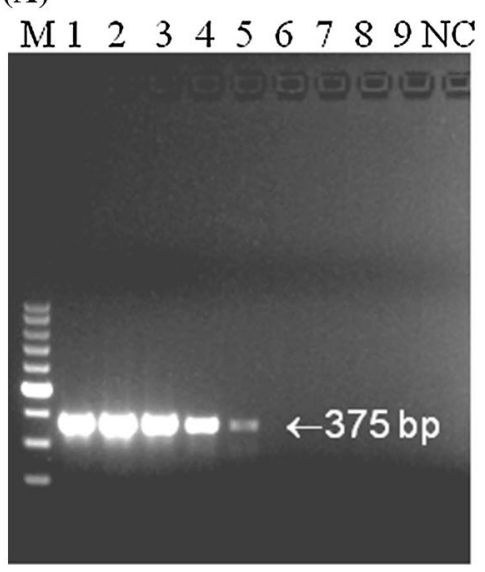

(B) $1 \quad 2 \quad 3 \quad 4 \quad 5 \quad 6 \quad 7 \quad 8 \quad 9 \quad \mathrm{NC}$

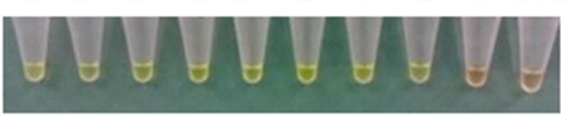

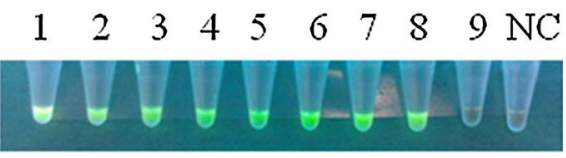

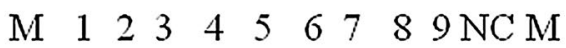

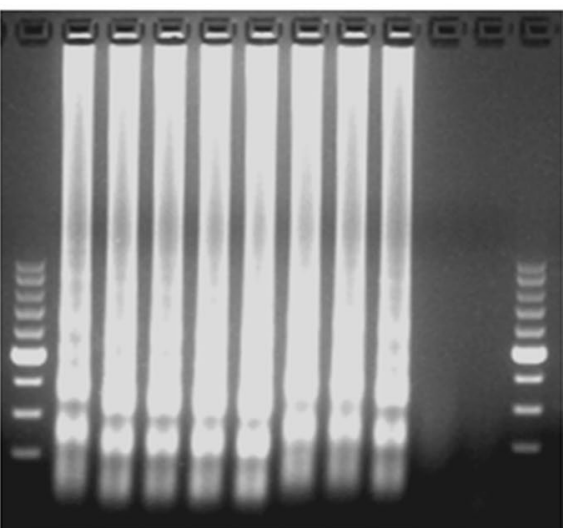


PCR

PCR was conducted using MSLF and MssR primers as previously described (Wetzel et al. 2010). Reaction was carried out in a final volume of $25 \mu$ containing $12.5 \mu \mathrm{l}$ of Taq PCR Master Mix (EurX, Gdansk, Poland), 10 pM of each MsLF and MSsR primer and $7.5 \mu$ l deionised water. The thermal profile was $94{ }^{\circ} \mathrm{C}$ for $2 \mathrm{~min}$, followed by 35 cycles of $94{ }^{\circ} \mathrm{C}$ for $30 \mathrm{~s} ; 55^{\circ} \mathrm{C}$ for $30 \mathrm{~s} ; 72{ }^{\circ} \mathrm{C}$ for $60 \mathrm{~s}$ and final extension at $72{ }^{\circ} \mathrm{C}$ for $7 \mathrm{~min}$. The PCR products were separated in $2 \%$ agarose gel stained with ethidium bromide $(0.5 \mu \mathrm{g} / \mathrm{ml})$. The length of PCR products was compared to 100-bp DNA Ladder Plus GeneRuler ${ }^{\mathrm{TM}}$ (Thermo-scientific, Waltham, Massachusetts, USA).

\section{Results}

\section{LAMP conditions}

In order to determine the optimal conditions of LAMP, MS reference strain (ATCC 25204) was used as the target template. LAMP assays were incubated under isothermal condition between 56 and $70{ }^{\circ} \mathrm{C}$. The specific colour change, greenish fluorescence and amplicons were observed at $66.3^{\circ} \mathrm{C}$, but in case of field MS strains, the optimal temperature was $63.0^{\circ} \mathrm{C}$. The optimal LAMP duration time was $60 \mathrm{~min}$. Longer incubation up to $105 \mathrm{~min}$ had no influence on the final results. Therefore, the final LAMP conditions for all strains was $63{ }^{\circ} \mathrm{C}$ for $60 \mathrm{~min}$ then $80^{\circ} \mathrm{C}$ for $2 \mathrm{~min}$ to deactivate the polymerase.

\section{Analytical sensitivity and specificity of LAMP}

The analytical sensitivity of LAMP showed that the detection limit was $10^{-1} \mathrm{CFU} / \mathrm{ml}$ of MS reference strain (ATCC 25204) and was 1,000 times higher in comparison with conducted PCR (Fig. 1). LAMP was specific only for the reference strain of MS. No colour change, fluorescence nor ladder-like pattern was observed in LAMP samples containing other species of Mycoplasma (Fig. 2). This indicated high analytical specificity of established LAMP assay for the selective detection of MS.

Field samples of MS

All 18 field isolates of MS were positive in conducted MS-specific PCR (data not shown). The similar results were obtained using developed LAMP. The colour change of reaction mixtures and specific ladder-like pattern was detected in reference MS strain as well as in all 18 field isolates (Fig. 3). This indicated on the capability of LAMP to detect both reference and field MS isolates.
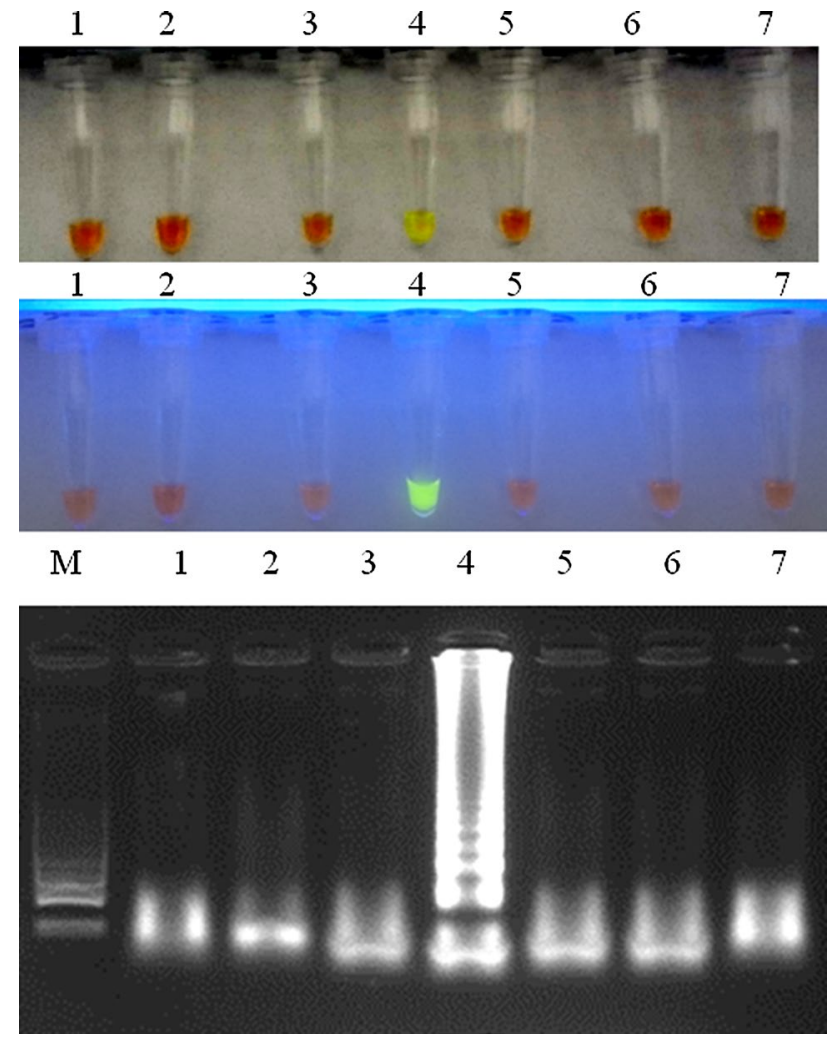

Fig. 2 Analytical specificity of LAMP for MS detection. Visible colour change in MS-positive samples, greenish fluorescence under UV light and specific ladder-like patter after gel electrophoresis. Descriptions $M$ molecular length marker GeneRuler ${ }^{\mathrm{TM}} 100$ bp DNA Ladder Plus (Thermo-scientific, Waltham, Massachusetts, USA), $1 \mathrm{M}$. gallisepticum (ATCC 19610), 2 M. meleagridis (ATCC 25284), 3 M. iowae (ATCC 33552), 4 M. synoviae strain (ATCC 25204), 5 M. anatis (ATCC 25524), 6 M. anseris (ATCC 49234) and 7 M. cloacale (ATCC 35276)

\section{Discussion}

Until now, MS culturing methods, serological assays and conventional PCRs or real-time PCRs are useful in detection of MS strains (Lauerman et al. 1993; Hong et al. 2004; Hess et al. 2007; Feberwee et al. 2008; Dijkman et al. 2013). However, culturing is very laborious, time consuming and requires specific growth medium and incubation (Ratliff et al. 2014). PCR is highly specific and sensitive technique but requires at least few hours, and electrophoresis is needed to visualize the results. Indeed, it has been previously presented that multiplex PCR is a valuable tool for the detection or differentiation of MG and MS in chickens (Garcia et al. 1995; Hess et al. 2007; Hammond et al. 2009; Wetzel et al. 2010; Fraga et al. 2013). Moreover, using PCR and PCR-RFLP method targeted on single-copy domain of the N-terminal $v$ lhA region, it is possible to differentiate field MS isolates from MS-H vaccine strain (Bayatzadeh et al. 2014). 
Fig. 3 Analysis of field MS isolates by LAMP. a Ladderlike pattern in MS-positive samples after gel electrophoresis, $\mathbf{b}$ visible colour change in MS-positive samples, $\mathbf{c}$ greenish fluorescence under UV light. Descriptions $M$ molecular length marker GeneRuler ${ }^{\mathrm{TM}}$ 100 bp DNA Ladder Plus (Thermo-scientific, Waltham, Massachusetts, USA), 1-18 field MS isolates, $N C$ negative control-DNA extracted from non-inoculated growth medium, $P C$ positive control DNA of reference $M$. synoviae strain (ATCC 25204)

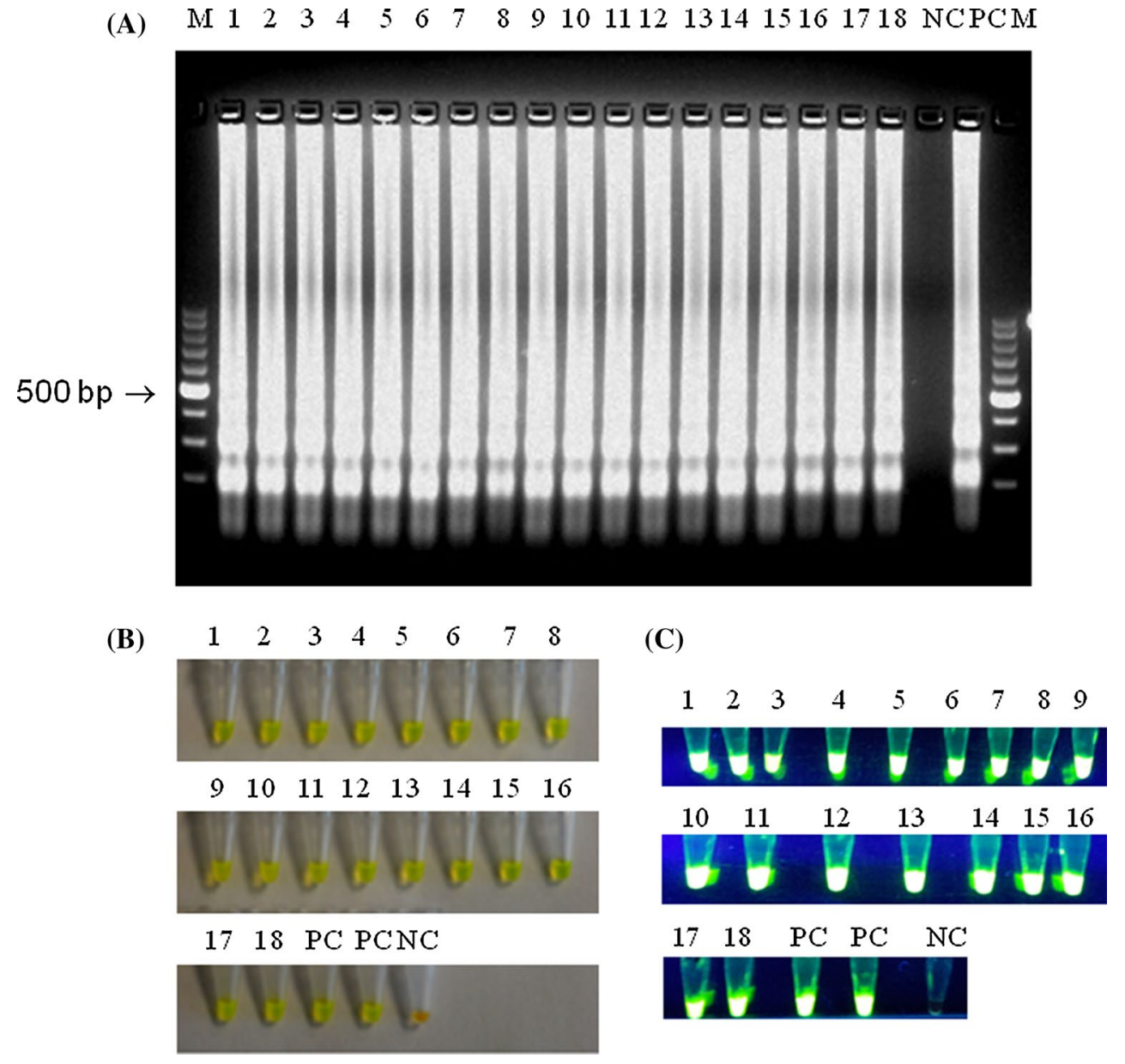

Based on 16S-23S rRNA intergenic spacer region, it was also possible to quantify MS copy number in samples collected from chicken joints using specific qPCR technique (Raviv and Kleven 2009; Dijkman et al. 2013). An attractive alternative to traditional methods of MS detection is LAMP which is simple to set and requires no additional thermal cyclers (Woźniakowski et al. 2012). Previously, LAMP has been applied for detection of $M$. hyorhinis in specimens of bronchoalveolar lavage fluid (BALF) from pigs (Du et al. 2013). The analytical sensitivity of LAMP reached ten DNA copies per $\mathrm{ml}$ that was 1,000 times higher than in case of conventional PCR. Indeed, in our study, LAMP showed to be very sensitive detecting $10^{-1}$ $\mathrm{CFU} / \mathrm{ml}$ of standard MS strain. Other study published by Mair et al. (2013) showed LAMP usefulness for detection of M. mycoides subsp. mycoides as the technique that may be run on a battery-driven mobile device. The efficacy of LAMP was also confirmed in the study on detection of M. pneumoniae (MP) as the lower respiratory tract pathogen in children (Ratliff et al. 2014). Similar example of LAMP application for the detection of $M$. wenyonii in cattle was presented by Song et al. (2012). The conducted study on development of LAMP for MS identification provides an additional evidence of the usefulness of this technique as a rapid and very sensitive method for Mycoplasma ssp. detection.

\section{Conclusions}

In conclusion, the developed LAMP showed to be a powerful and robust method for the specific and selective detection of M. synoviae. Using specific region of vlhA gene, it was possible to selectively amplify DNA of MS without cross-reactions in other samples containing DNA of $\mathrm{Myco}$ plasma spp. This method presents an useful alternative for local veterinarians and small veterinary laboratories without an access to PCR technique.

Conflict of interest The authors declare that they have no competing interests. 
Open Access This article is distributed under the terms of the Creative Commons Attribution License which permits any use, distribution, and reproduction in any medium, provided the original author(s) and the source are credited.

\section{References}

Bayatzadeh MA, Pourbakhsh SA, Ashtari A, Abtin AR, Abdoshah M (2014) Molecular typing of Iranian field isolates Mycoplasma synoviae and their differentiation from the live commercial vaccine strain MS-H using vlhA gene. Br Poult Sci 55:148-156

Catania S, Bilato D, Gobbo F, Granato A, Terregino C, Iob L, Nicholas RA (2010) Treatment of eggshell abnormalities and reduced egg production caused by Mycoplasma synoviae infection. Avian Dis 54:961-964

Dijkman R, Feberwee A, Landman WJ (2013) Validation of a previously developed quantitative polymerase chain reaction for the detection and quantification of Mycoplasma synoviae in chicken joint specimens. Avian Pathol 42:100-107

Du GM, Liu MJ, Wu YZ, Xiong QY, Bai FF, Feng ZX, Shao GQ (2013) Development of a loop-mediated isothermal amplification assay for rapid detection of Mycoplasma hyorhinis. Clin Lab 59:1363-1371

Ewing L, Cookson KC, Phillips RA, Turner KR, Kleven SH (1998) Experimental infection and transmissibility of Mycoplasma synoviae with delayed serological response in chickens. Avian Dis 42:230-238

Feberwee A, de Vries TS, Landman WJ (2008) Seroprevalence of Mycoplasma synoviae in Dutch commercial poultry farms. Avian Pathol 37:629-633

Feberwee A, de Wit JJ, Landman WJ (2009) Induction of eggshell apex abnormalities by Mycoplasma synoviae: field and experimental studies. Avian Pathol 38:77-85

Ferguson-Noel N, Noormohammadi AH (2013) Mycoplasma synoviae infection. In: Swayne DE, Glisson JR, McDougald LR, Nolan LK, Suarez DL, Nair VL (eds) Diseases of poultry, 13th edn. Wiley, Ames, pp 900-906

Fiorentin L, Soncini RA, da Costa JL, Mores MA, Trevisol IM, Toda M, Vieira ND (2003) Apparent eradication of Mycoplasma synoviae in broiler breeders subjected to intensive antibiotic treatment directed to control Escherichia coli. Avian Pathol 32:213-216

Fraga AP, de Vargas T, Ikuta N, Fonseca AS, Celmer AJ, Marques EK, Lunge VR (2013) A multiplex real-time PCR for detection of Mycoplasma gallisepticum and Mycoplasma synoviae in clinical samples from Brazilian commercial poultry flocks. Braz J Microbiol 44:505-510

Fu S, Qu G, Guo S, Ma L, Zhang N, Zhang S, Gao S, Shen Z (2011) Applications of loop-mediated isothermal DNA amplification. Appl Biochem Biotechnol 163:845-850

Garcia M, Jackwood MW, Levisohn S, Kleven SH (1995) Detection of Mycoplasma gallisepticum, M. synoviae, and M. iowae by multi-species polymerase chain reaction and restriction fragment length polymorphism. Avian Dis 39:606-616

Hammond PP, Ramírez AS, Morrow CJ, Bradbury JM (2009) Development and evaluation of an improved diagnostic PCR for Mycoplasma synoviae using primers located in the haemagglutinin encoding gene $v l h A$ and its value for strain typing. Vet Microbiol 136:61-68

Hess M, Neubauer C, Hackl R (2007) Interlaboratory comparison of ability to detect nucleic acid of Mycoplasma gallisepticum and Mycoplasma synoviae by polymerase chain reaction. Avian Pathol 36:127-133

Hong Y, Garcia M, Leiting V, Bencina D, Dufour-Zavala L, Zavala G, Kleven SH (2004) Specific detection and typing of Mycoplasma synoviae strains in poultry with PCR and DNA sequence analysis targeting the hemagglutinin encoding gene $v \operatorname{lh} A$. Avian Dis 48:606-616

Huang CH, Lai GH, Lee MS, Lin WH, Lien YY, Hsueh SC, Kao JY, Chang WT, Lu TC, Lin WN, Chen HJ, Lee MS (2010) Development and evaluation of a loop-mediated isothermal amplification assay for rapid detection of chicken anemia virus. J Appl Microbiol 108:917-924

Jordan FTW (1975) Avian Mycoplasma and pathogenicity—a review. Avian Pathol 4:165-174

Kakuya F, Kinebuchi T, Fujiyasu H, Tanaka R, Kano H (2014) Genetic point-of-care diagnosis of Mycoplasma pneumoniae infection using LAMP assay. Pediatr Int 56:547-552

King DD, Kleven SH, Wenger DM, Anderson DP (1973) Field studies with Mycoplasma synoviae. Avian Dis 17:722-726

Kleven SH (2003) Mycoplasma synoviae. In: Saif YM (ed) Diseases of poultry, 11th edn. Iowa State University Press, Ames, pp 756-765

Kleven SH, Fletcher OJ, Davis RB (1975) Influence of strain of Mycoplasma synoviae and route of infection on development of synovitis or airsacculitis in broilers. Avian Dis 19:126-135

Landman WJ (2014) Is Mycoplasma synoviae outrunning Mycoplasma gallisepticum? A viewpoint from the Netherlands. Avian Pathol 43:2-8

Landman WJM, Feberwee A (2004) Aerosol-induced Mycoplasma synoviae arthritis: the synergistic effect of infectious bronchitis virus infection. Avian Pathol 33:591-598

Lauerman LH, Hoerr FJ, Sharpton AR, Shah SM, van Santen VL (1993) Development and application of a polymerase chain reaction assay for Mycoplasma synoviae. Avian Dis 37:829-834

Mair G, Vilei EM, Wade A, Frey J, Unger H (2013) Isothermal loopmediated amplification (LAMP) for diagnosis of contagious bovine pleuro-pneumonia. BMC Vet Res 9:108

Notomi T, Okayama H, Masubuchi H, Yonekawa T, Watanabe K, Amino N (2000) Loop-mediated isothermal amplification of DNA. Nucleic Acids Res 28:E63

Olson NO, Shelton DC, Bletner JK, Munro DA, Anderson GC (1956) Studies of infectious synovitis in chickens. Am J Vet Res 17:747-754

Ratliff AE, Duffy LB, Waites KB (2014) Comparison of the illumigene Mycoplasma DNA amplification assay and culture for detection of Mycoplasma pneumoniae. J Clin Microbiol 52:1060-1063

Raviv Z, Kleven SH (2009) The development of diagnostic real-time TaqMan PCRs for the four pathogenic avian mycoplasmas. Avian Dis 53:103-107

Reck C, Menin A, Canever MF, Milettia LC (2013) Rapid detection of Mycoplasma synoviae and avian reovirus in clinical samples of poultry using multiplex PCR. Avian Dis 57:220-224

Saito R, Misawa Y, Moriya K, Koike K, Ubukata K, Okamura N (2005) Development and evaluation of a loop-mediated isothermal amplification assay for rapid detection of Mycoplasma pneumoniae. J Med Microbiol 54:1037-1041

Salisch H, Hinz KH, Graack HD, Ryll MA (1998) A comparison of a commercial PCR-based test to culture methods for detection of Mycoplasma gallisepticum and Mycoplasma synoviae in concurrently infected chickens. Avian Pathol 27:142-147

Song Q, Wang L, Fang R, Khan MK, Zhou Y, Zhao J (2012) Detection of Mycoplasma wenyonii in cattle and transmission vectors by the loop-mediated isothermal amplification (LAMP) assay. Trop Anim Health Prod 45:247-250

Stipkovits L, Kempf I (1996) Mycoplasmoses in poultry. Rev Sci Tech 15:1495-1525

Wetzel AN, Lefevre KM, Raviv Z (2010) Revised Mycoplasma synoviae vlhA PCRs. Avian Dis 54:1292-1297 
Woźniakowski G, Samorek-Salamonowicz E, Kozdruń W (2011) Rapid detection of Marek's disease virus in feather follicles by loop-mediated amplification. Avian Dis 55:462-467

Woźniakowski G, Kozdruń W, Samorek-Salamonowicz E (2012) Loop-mediated isothermal amplification for the detection of goose circovirus. Virol J 9:110
Yang JL, Rui Y, Cheng AC, Wang MS, Fu LZ, Yang SQ, Zhang SH, Yang L, Xu ZY (2010) A simple and rapid method for detection of goose parvovirus in the field by loop mediated isothermal amplification. Virol J 7:14 